\title{
Cryptonemia rotunda (Halymeniales) and Schizymenia apoda (Nemastomatales), two new records of red algae from Korea
}

\author{
Su Yeon Kim ${ }^{1}$, Tae Ho Seo ${ }^{2}$, Jeong Kwang Park ${ }^{1}$, Ga Hun Boo ${ }^{1}$, Kyeong Mi Kim ${ }^{1}$ and \\ Sung Min Boo ${ }^{1, *}$
}

${ }^{1}$ Department of Biology, Chungnam National University, Daejeon 305-764, Korea

${ }^{2}$ Department of Aqualife Science, Chonnam National University, Yeosu 550-749, Korea

\begin{abstract}
Here we report the first finding of Cryptonemia rotunda and Schizymenia apoda in Korea based on plastid rbcL sequence analysis and morphological observations. C. rotunda occurred in the subtidal in Hongdo and Namyeodo on the south coast. Thalli have short stipe with foliose, membranous blades with dentate margin, a length of 2-8 cm. S. apoda occurred in many locations along the coast of Korea. Thalli are foliose, simple or broadly lanceolate blades with irregular lobes and proliferations from the margins, sometimes undulate, soft fleshy, and slippery, up to $32 \mathrm{~cm}$ tall, and have cystocarps with ostioles on the blade. Plastid $r b c \mathrm{~L}$ sequences reveal that each of these species is clearly separated from other species of their respective genera. S. apoda was well resolved within the genus. However, C. rotunda was distantly related to other members of the genus, and this result needs an urgent revision of the genus.
\end{abstract}

Key Words: Cryptonemia rotunda; molecular systematics; Rhodophyta; Schizymenia apoda

\section{INTRODUCTION}

Cryptonemia J. Agardh (Halymeniaceae) is a foliose red algal genus comprising of 43 species that are distributed from warm to cold temperate regions of the world (Guiry and Guiry 2011). The genus Cryptonemia, typified with C. lomation (Bertoloni) J. Agardh, is distinguished by the well-developed stipe and / or midrib, highly refractive medullary cells, and bushy ampullar filaments with up to four orders (Chiang 1970, Womersley 1994). In Korea, two species of Cryptonemia are reported; C. lomation [as C. lactuca (C. Agardh) J. Agardh, Lee 2008; see Guiry and Guiry 2011 for synonymy] and C. tuniformis (= C. tunaeformis) (Bertoloni) Zanardini (Kang 1966). Both species are rarely found in Korea (Kang 1966, Lee and Kang 2001, Lee 2008).

Schizymenia J. Agardh (Schizymeniaceae) consists of
10 species that are distributed in temperate and tropical waters, ranging from the subantarctic islands to Alaska (Gabriel et al. 2011, Guiry and Guiry 2011). It is distinguished by the presence of the gland cells resembling large, inverted tears, located terminally on cortical filaments (Dixon and Irvine 1977, Gabriel et al. 2011). Only Schizymenia dubyi (Chauvin ex Duby) J. Agardh is listed to date in the Korean inventory of marine algae (Kang 1966, Lee and Kang 2001, Lee 2008).

During floristic study of Korean marine algae, we found two unrecorded species; Cryptonemia rotunda (Okamura) Kawaguchi and Schizymenia apoda (J. Agardh) J. Agardh. In the present study, we analyzed $r b c L$ sequences of both species together with previously recorded $S$. dubyi through extensive collections along the coasts of Korea, (c) This is an Open Access article distributed under the terms of the Creative Commons Attribution Non-Commercial License (http://creativecommons.org/licenses/by-nc/3.0/) which permits unrestricted non-commercial use, distribution, and reproduction in any medium, provided the original work is properly cited.
Received January 5, 2012, Accepted February 15, 2012

*Corresponding Author

E-mail: smboo@cnu.ac.kr

Tel: +82-42-821-6555, Fax: +82-42-822-9690 
observing details of morphology. Published sequences of species of Cryptonemia and Schizymenia (Kawaguchi et al. 2004, Gabriel et al. 2011, Huisman et al. 2011) allow us to directly compare our results with others from these two genera as a whole and with putative relatives. We found that both Cryptonemia and Schizymenia have the deep taxonomic problem and the lack of update in many areas of the world.

\section{MATERIALS AND METHODS}

\section{Taxon sampling and morphology}

Field collections of Cryptonemia and Schizymenia were made at many locations in Korea (Table 1). Materials were collected from intertidal zone or subtidal zone using SCUBA diving. Tissues were sectioned with a freezing microtome (FX-80; Yamato Kohki Industrial Co. Ltd., Saitama, Japan). Photographs were taken with a DP-71 camera (Olympus, Tokyo, Japan) attached to a microscope (BX 51; Olympus). Voucher specimens are housed at the herbarium of Chungnam National University, Daejeon, Korea (CNUK).

\section{Analysis of $r b c L$ sequences}

Forty-one specimens were available for extraction of DNA: 10 for C. rotunda, 7 for S. apoda, 24 for S. dubyi (Table 1). DNA extraction, polymerase chain reaction amplification, and sequencing follow Boo et al. (2010). Primer pairs for amplification and sequencing of $r b c \mathrm{~L}$ were as follows: rbcLF145-rbcLR898 and rbcLF762-rbcLR1442 (Kim et al. 2010).

Table 1. Materials used in the present study

\begin{tabular}{|c|c|c|c|}
\hline Taxa & Collection data & Voucher & GenBank accession No. \\
\hline \multirow{2}{*}{$\begin{array}{l}\text { Cryptonemia rotunda } \\
\text { (Okamura) Kawaguchi }\end{array}$} & Hongdo, Geojaedo, Korea; Jul 24, 2011 (2) & SH500 & Same as JQ362446 \\
\hline & Namyeodo, Geojaedo, Korea; Nov 3, 2011 (8) & SH341 & JQ362446 \\
\hline \multirow{6}{*}{$\begin{array}{l}\text { Schizymenia apoda } \\
\text { (J. Agardh) J. Agardh }\end{array}$} & Dolsando, Yesu, Korea; Mar 20, 2011 (2) & CNU1236 & Same as JQ362442 \\
\hline & Hoidong, Jindo, Korea; Mar 1, 2010 & S236 & Same as JQ362442 \\
\hline & Hoidong, Jindo, Korea; Apr 5, 2008 & G1101 & JQ362441 \\
\hline & Ilkwang, Busan, Korea; Apr 4, 2011 & CNU8698 & JQ362442 \\
\hline & Namaehang, Yangyang, Korea; Feb 19, 2011 & SH168 & Same as JQ362442 \\
\hline & Seogeochado, Jindo, Korea; Apr 6, 2008 & G849 & Same as JQ362441 \\
\hline \multirow{19}{*}{$\begin{array}{l}\text { Schizymenia dubyi } \\
\text { (Chauvin ex Duby) J. Agardh }\end{array}$} & Anin, Gangneung, Korea; Feb 18, 2011 (3) & SH171 & Same as JQ362444 \\
\hline & Anin, Gangneung, Korea; Dec 21, 2011 & SH361 & Same as JQ362444 \\
\hline & Cheongjinri, Pohang, Korea; Feb 18, 2011 & SH169 & Same as JQ362443 \\
\hline & Gamchusa, Donghae, Korea; Mar 14, 2010 & $\mathrm{SH} 4$ & Same as JQ362444 \\
\hline & Gamchusa, Donghae, Korea; Dec 21, 2011 & SH356 & Same as JQ362444 \\
\hline & Gijang, Busan, Korea; Feb 28, 2010 & SH1 & Same as JQ362443 \\
\hline & Jeoncheon, Donghae, Korea; Apr 8, 2011 (2) & CNU1348 & JQ362444 \\
\hline & Jeoncheon, Donghae, Korea; Mar 14, 2010 (2) & SH6 & Same as JQ362444 \\
\hline & Namae Port, Yangyang, Korea; Feb 8, 2010 & G7057 & Same as JQ362444 \\
\hline & Sacheon, Gangreung, Korea; Apr 8, 2011 (2) & CNU1356 & Same as JQ362444 \\
\hline & Sanbangsan, Jeju, Korea; Mar 13, 2009 & G1868 & Same as JQ362444 \\
\hline & Sagye, Jeju, Korea; Mar 14, 2009 & G1847 & JQ362445 \\
\hline & Sanbangsan, Jeju, Korea; Mar 13, 2009 & G1870 & Same as JQ362445 \\
\hline & Sodol, Gangneung, Korea; Apr 12, 2008 & G802 & Same as JQ362444 \\
\hline & Sodol, Gangneung, Korea; Mar 13, 2010 & G7064 & Same as JQ362444 \\
\hline & Suryeomri, Gyeongju, Korea; Apr 4, 2011 & CNU8728 & JQ362443 \\
\hline & Dalian, China; Nov 13, 2008 & G1690 & Same as JQ362443 \\
\hline & Tsuyazaki, Fukuoka, Japan; May 18, 2011 & CNU9027 & Same as JQ362444 \\
\hline & Tsuyazaki, Fukuoka, Japan; May 18, 2011 & CNU9028 & Same as JQ362445 \\
\hline
\end{tabular}

The numeral in parenthesis indicates the number of specimens analyzed. 


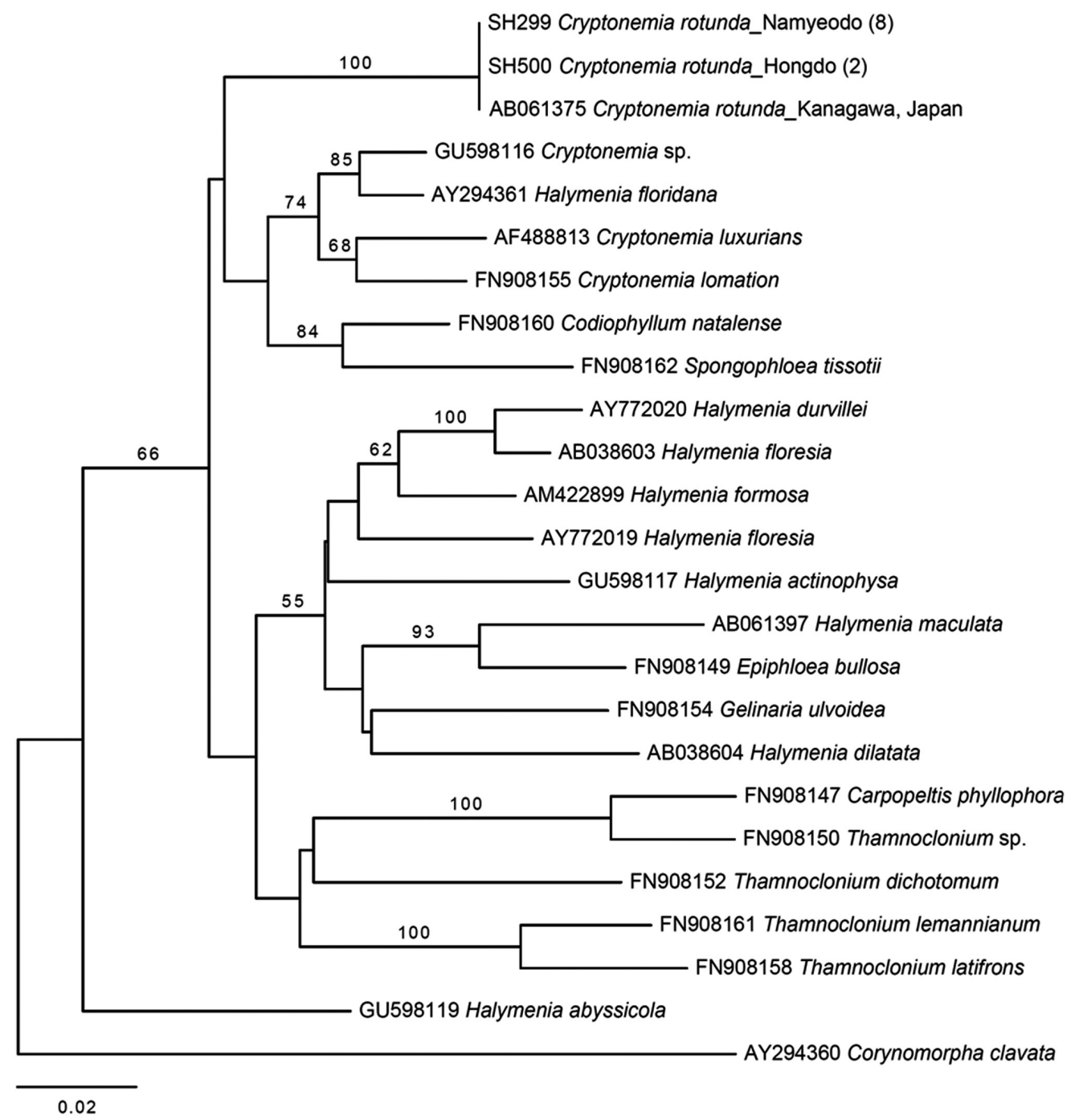

Fig. 1. Maximum likelihood (ML) tree of Cryptonemia rotunda inferred from $r b c L$ sequences calculated using the GTR $+\lceil$ model. Numeral in parenthesis indicates the number of specimens with identical sequences. ML bootstrap values $(\geq 50)$ are shown for each clade.

\section{Phylogenetic analyses}

Maximum likelihood (ML) phylogenetic analysis of $r b c \mathrm{~L}$ was performed using the GTR $+\Gamma$ model implemented in RAxML software (Stamatakis 2006). We used 200 independent tree inferences with the 'number of run' option, with default optimized subtree pruning and regrafting rearrangement and 25 distinct rate categories to identify the best tree. Statistical support for each branch was obtained from 1,000 bootstrap replications using the same substitution model and RAxML program settings.

\section{RESULTS}

\section{Cryptonemia rotunda (Okamura) Kawaguchi}

Molecular analyses. Thirty-three $r b c \mathrm{~L}$ sequences consisting of 23 taxa of Halymeniaceae including ten new sequences of $C$. rotunda analyzed in the present study were aligned with 1,129 bp. All Cryptonemia specimens collected from Hongdo and Namyeodo belong to a single species consistent with the GenBank sequence of $C$. rotunda from Japan (Fig. 1).

Plastid $r b c \mathrm{~L}$ tree revealed that the genus Cryptonemia was not monophyletic (Fig. 1). C. rotunda was not monophyletic with the other members of the genus. The pairwise divergence between C. rotunda and Halymenia floridana was $5.2 \%$, while C. rotunda was in distance of $5.6-6.3 \%$ from other members of the genus. 
A
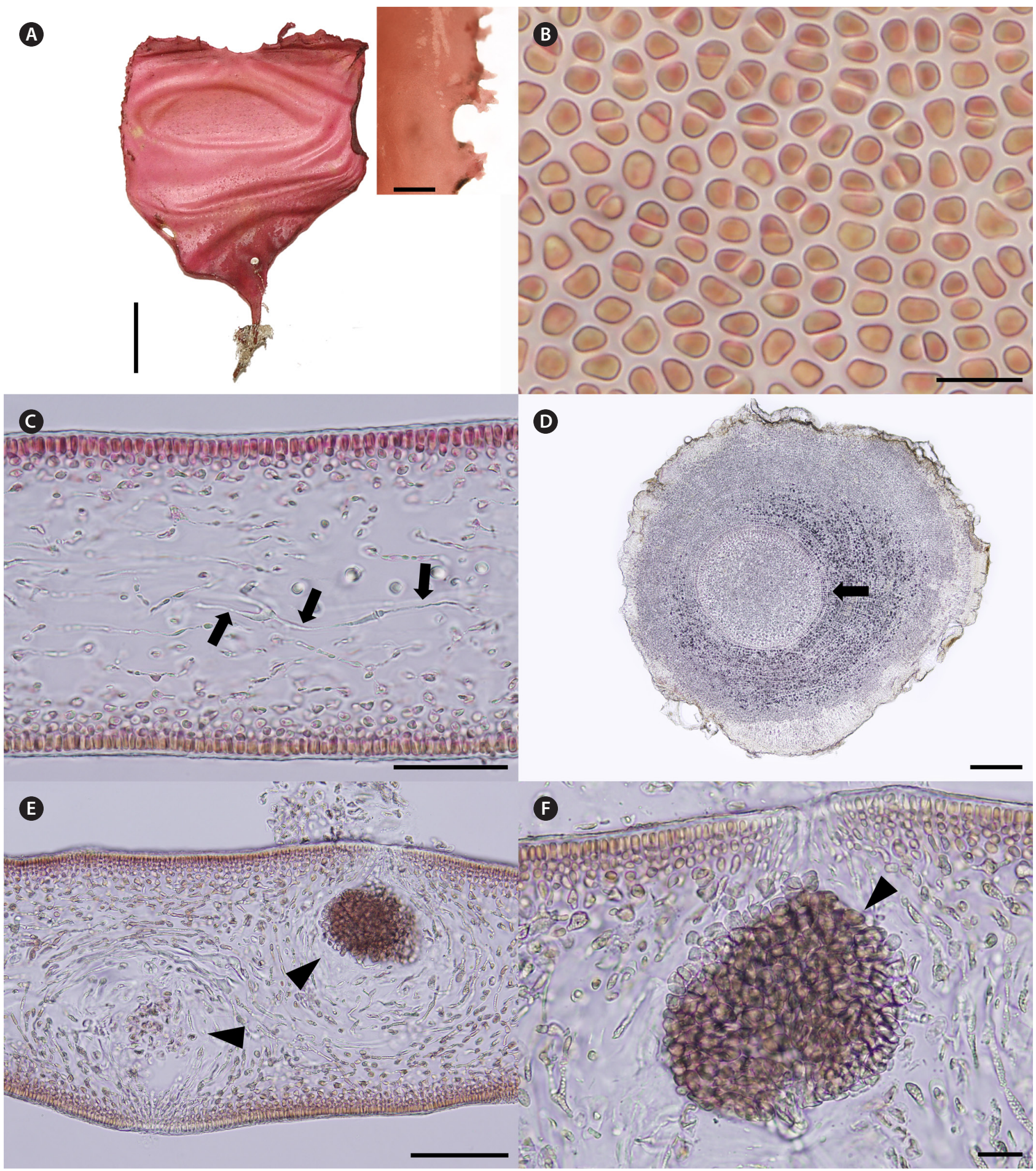

Fig. 2. Cryptonemia rotunda (Okamura) Kawaguchi. (A) Morphology of thallus with stipe and small protuberances in margin (upper right). (B) Angular cells on the surface of thallus. (C) Cross section of blade showing refractive cells (arrows). (D) Cross section of stipe showing growth rings (arrow). (E) Cross section of female plant having cystocarps (arrowheads). (F) Magnification of Fig. 2E showing mature cystocarp (arrowhead). Scale bars represent: $A, 1 \mathrm{~cm}$; inset in $A, 200 \mu \mathrm{m} ; \mathrm{B}, 10 \mu \mathrm{m} ; \mathrm{C}, 50 \mu \mathrm{m} ; \mathrm{D}, 200 \mu \mathrm{m} ; \mathrm{E}, 100 \mu \mathrm{m} ; \mathrm{F}, 20 \mu \mathrm{m}$. 


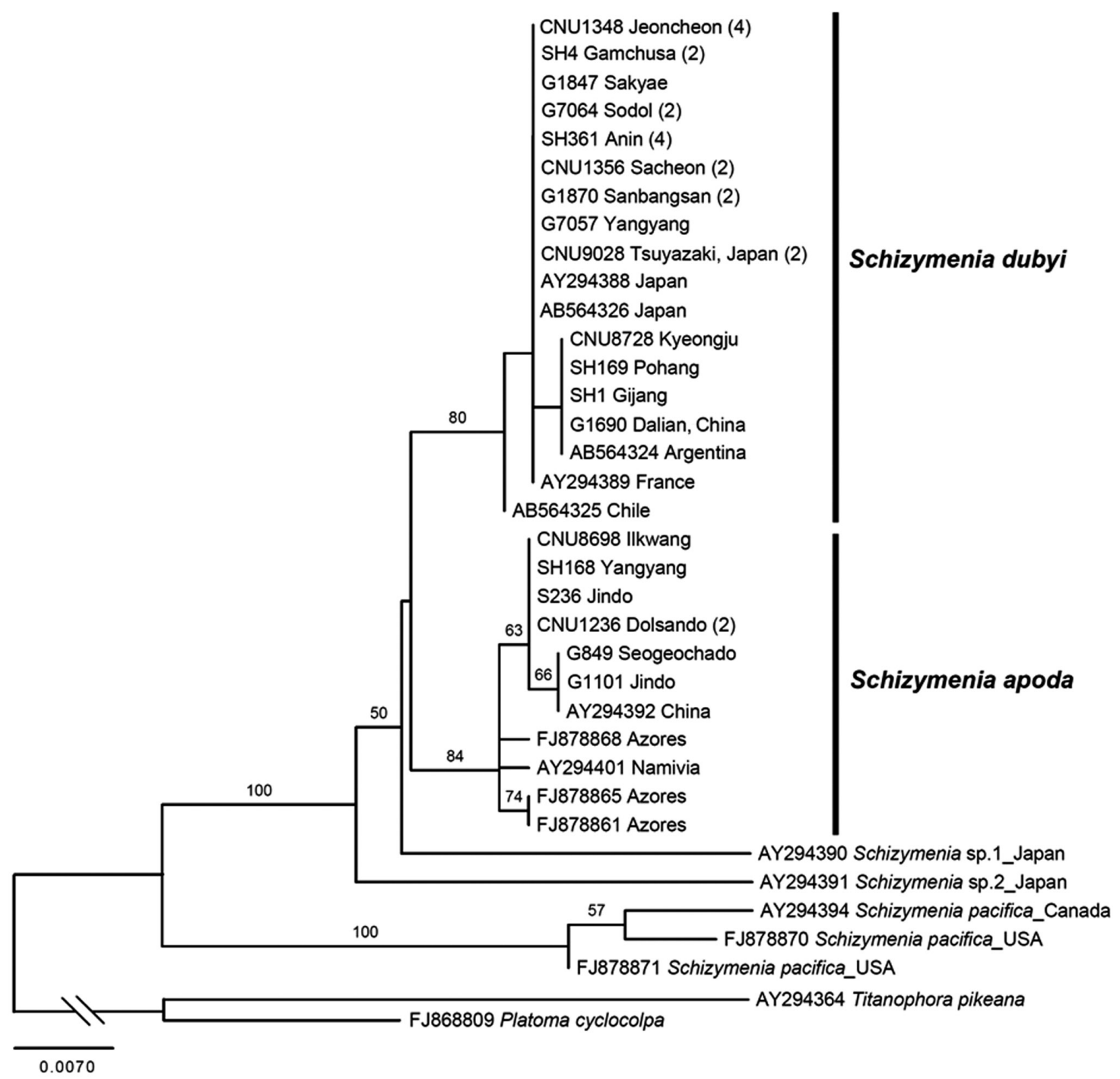

Fig. 3. Maximum likelihood (ML) tree of Schizymenia apoda inferred from $r b c L$ sequences calculated using the GTR $+\Gamma$ model. Numeral in parenthesis indicates the number of specimens with identical sequences. ML bootstrap values $(\geq 50)$ are shown for each clade.

Korean name. 둥근바다선인장 (신칭) (Fig. 2A-F)

Description. Thalli are medium to dark red, membranous, circular or ellipsoid, rarely irregularly shaped, up to $8 \mathrm{~cm}$ in length and $4 \mathrm{~cm}$ in width, expanding from a stipe (Fig. 2A). Blades are thickened along the margin and beset with numerous, small protuberances, looking toothed (Fig. 2A), up to $200 \mu \mathrm{m}$ thick (margins 300-370 $\mu \mathrm{m}$ thick). Cells at the surface of blade are angular (Fig. 2B). Tissue consists of cortex and medulla (Fig. 2C). Cortices are compact with 2-5 layers of cortical cells and 20-30 $\mu \mathrm{m}$ thick. Medulla are 120-180 $\mu \mathrm{m}$ thick, of entwined refractive filaments $1-4 \mu \mathrm{m}$ in diameter (Fig. 2C). Holdfasts are discoid, 1-3 $\mathrm{mm}$ across, bearing stiff stipe which have several growth rings in cross section (Fig. 2D).

Female reproductive structures are scattered around upper side of the blade. Cystocarps (Fig. 2E \& F) are subglobose, $80-100 \mu \mathrm{m}$ across, and swollen on the surface of blades with small ostiole. Both male plants and tetrasporangial plants were not found.

Thalli grow on rocks at a depth of 14-18 $\mathrm{m}$ in the subtidal zones. Thalli are larger in July than in November.

\section{Schizymenia apoda (J. Agardh) J. Agardh}

Molecular analyses. A total of $48 \mathrm{rbcL}$ sequences of Schizymeniaceae including 31 new sequences were aligned with 503 bp. Seven specimens of Korean S. apoda clustered with those from China, the Azores, and Namibia (Fig. 3). Twenty-four specimens of $S$. dubyi from Korea clustered with those from China, Japan, Argentina, 
A
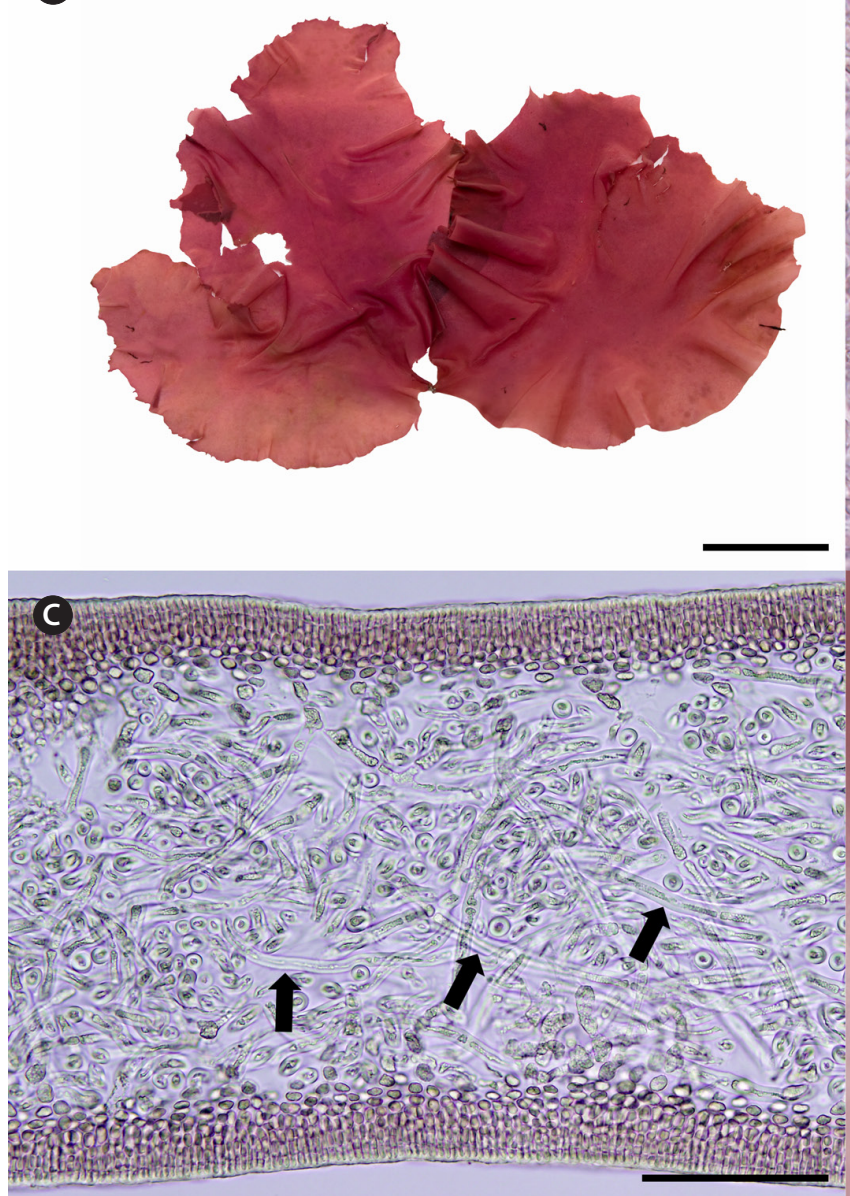

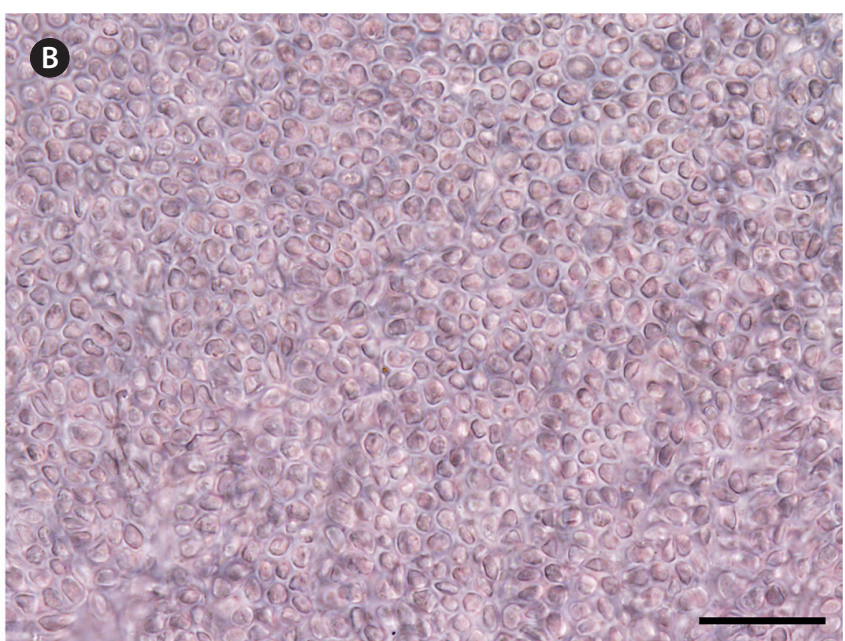

D

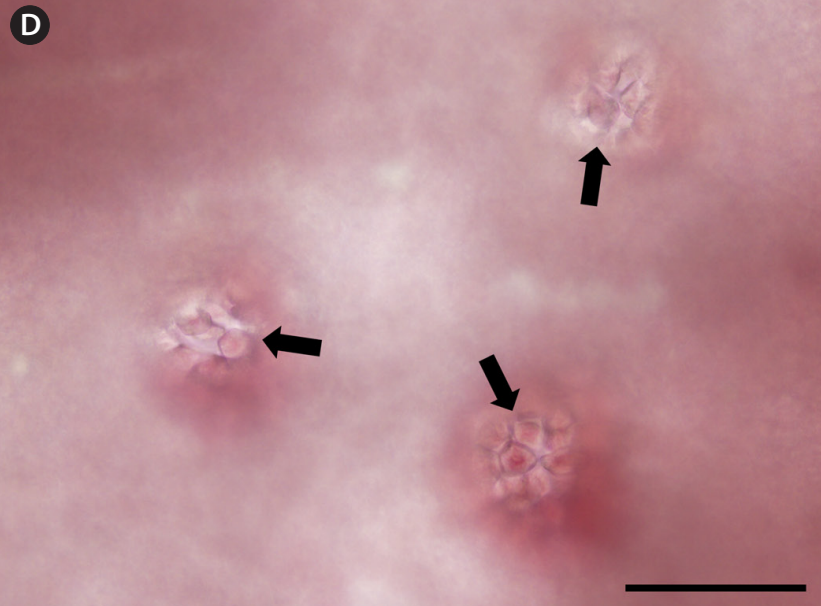

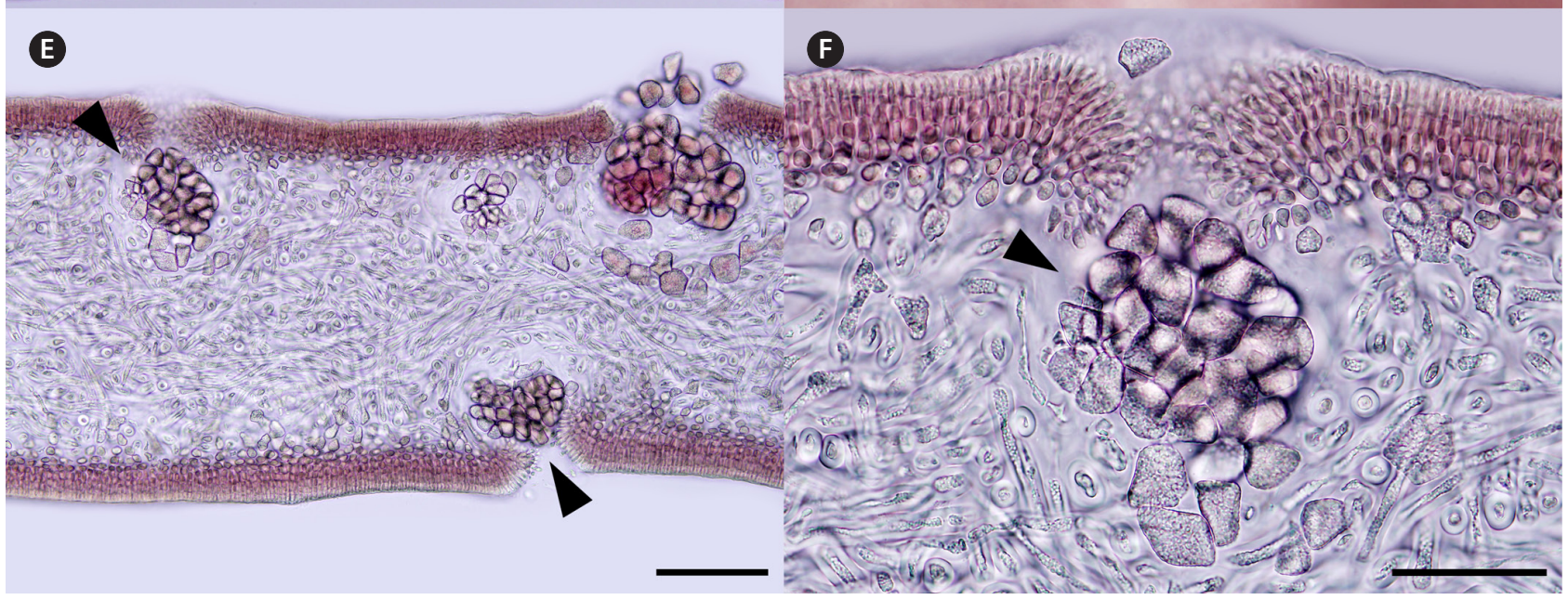

Fig. 4. Schizymenia apoda (J. Agardh) J. Agardh. (A) Morphology of thallus showing undulated margins. (B) Small angular cells on the surface of blade. (C) Transverse section of blade showing hyphae cells (arrows) in medulla. (D) Cystocarpic thallus showing ostioles on the surface of blade. (E) Cystocarps (arrowheads) on both side of blade. (F) Enlarged view of Fig. 4E. Scale bars represent: A, 5 cm; B, $20 \mu \mathrm{m} ; \mathrm{C}-\mathrm{E}, 100 \mu \mathrm{m} ; \mathrm{F}, 50 \mu \mathrm{m}$. 
France and Chile.

Korean name. 자루갈래 잎 (신칭) (Fig. 4A-F)

Description. Thalli are bright to dark red, soft fleshy, circular or ellipsoid with undulated margins, up to $32 \mathrm{~cm}$ in length and $15 \mathrm{~cm}$ in width (Fig. 4A). Cells at the surface of blade are irregularly elongate (Fig. 4B). Tissues are compactly composed, and 300-330 $\mu \mathrm{m}$ thick (Fig. 4C). Cortices are 5-8 layers of cortical cells and 40-60 $\mu \mathrm{m}$ thick. Medulla are composed of thin filaments that are densely interwoven with one another, and 200-240 $\mu \mathrm{m}$ thick.

Female reproductive structures are scattered over entire blade, and easily distinguished by visible ostioles (Fig. 4D). Cystocarps (Fig. 4E \& F) are subglobose, 40-80 $\mu \mathrm{m}$ across. Spermatangia and tetrasporangia are not found.

Thalli grow on the rock with coralline algae at intertidal zones. They were collected in February, March, and April from 2008 to 2011.

\section{DISCUSSION}

Plastid $r b c \mathrm{~L}$ sequences of ten specimens of $C$. rotunda collected from the subtidal in Hongdo and Namyeodo islets on the southeastern coast of Korea were identical with that (AB061375) of a Japanese specimen. Thalli have substantial stipe and circular, membranous blade, and highly refractive cells in medulla. Morphology and anatomy of the Korean specimens correspond well to the description of Okamura (1936, as Halymenia rotunda Okamura) and Kawaguchi (1993). This is the third species in the Korean Cryptonemia inventory, together with $C$. lomation and $C$. tuniformis. C. lomation and C. tuniformis from Korea are different from C. rotunda in having midribs (Kang 1966, Lee 2008). C. lomation occurs only in Udo, Jeju Island (Lee 2008), while C. tuniformis has not been reported after Kang $(1966,1968)$ who described it based on a single fragment cast up ashore in Jijindo, now included to Yeochon city, on south coast. Molecular analysis of C. lomation and C. tuniformis is necessary to confirm their genetic identities because both species are mainly distributed in Europe (see Guiry and Guiry 2011). The topology of our $r b c \mathrm{~L}$ tree is similar to that of previous studies on the family Halymeniaceae (Kawaguchi et al. 2004, Huisman et al. 2011). However, our tree reveals that Cryptonemia is not monophyletic and C. rotunda is distantly related to other species of Cryptonemia. More sampling is necessary for the urgent revision of the genus Cryptonemia.

The second species added to the algal inventory of Korea is $S$. apoda, which has, to date, been recorded in South Africa, Europe, and China (Gabriel et al. 2011). Thalli of
Korean S. apoda are similar to those from the Azores (Gabriel et al. 2011). Thalli are foliose, simple or broadly lanceolate blades with irregular lobes and proliferations from the margins, sometimes undulate, soft fleshy, and slippery, up to $32 \mathrm{~cm}$ tall. Cystocarps on the blade surface have ostioles. In the present study, we found $S$. apoda in the same (e.g., Namaehang in Yangyang) or nearby locations where $S$. dubyi was recorded in Korea (see Table 1). S. dubyi is very common from Sokcho to Guryongpo on the east coast, and Busan to Heuksando on the south coast (Kang 1966), and Jeju Island (Kang 1966, Lee 2008). The mixed occurrences of S. apoda with S. dubyi in Korea imply that $S$. apoda thalli have likely been misidentified as morphological variants of $S$. dubyi. Our results support the suggestion of Gabriel et al. (2011) that at least several of the Japanese S. dubyi records (e.g., Yoshida 1998) are likely to be S. apoda.

All specimens of Korean S. apoda always formed a clade with those from the Azores, China, and Namivia in rbcL phylogeny (Fig. 3). However, genetic diversity within $S$. apoda is likely higher than $S$. dubyi (up to $0.6 \%$ for S. apoda, $0.4 \%$ for $S$. dubyi). All specimens of $S$. dubyi in Korea formed a clade with those from Argentina, Chile, China, France and Japan. S. apoda and S. dubyi formed a sister clade.

Together with the previous study by Gabriel et al. (2011), our result demonstrates that both S. apoda and S. dubyi have disjunct global distributions: China, Korea, the Azores, Namivia for S. apoda and Argentine, Chile, China, France, Japan, and Korea for S. dubyi. It is interesting to study whether their disjunct distributions can be explained by either natural dispersal or anthropogenic transport, using more taxon sampling and more variable molecular markers such as mitochondrial cox 1 .

\section{ACKNOWLEDGEMENTS}

This work was supported by Marine Biotechnology grants, and by Marine Biodiversity Program from the Ministry of Land, Transportation, and Maritime Affairs, Korea to SMB. We appreciate Lawrence M. Liao for reading the draft.

\section{REFERENCES}

Boo, S. M., Kim, S. Y., Hong, I. S. \& Hwang, I. K. 2010. Reexamination of the genus Pterocladiella (Gelidiaceae, Rhodophyta) in Korea based on morphology and $r b c \mathrm{~L}$ 
sequences. Algae 25:1-9.

Chiang, Y. -M. 1970. Morphological studies of red algae of the family Cryptonemiaceae. Univ. Calif. Publ. Bot. 58:1-95.

Dixon, P. S. \& Irvine, L. M. 1977. Seaweeds of the British Isles. Vol. 1. Rhodophyta, Part 1. Introduction: Nemaliales, Gigartinales. British Museum (Natural History), London, $252 \mathrm{pp}$.

Gabriel, D., Schils, T., Parente, M. I., Draisma, S. G. A., Neto, A. I. \& Fredericq, S. 2011. Taxonomic studies in the Schizymeniaceae (Nemastomatales, Rhodophyta): on the identity of Schizymenia sp. in the Azores and the generic placement of Nemastoma confusum. Phycologia 50:109121.

Guiry, M. D. \& Guiry, G. M. 2011. AlgaeBase. World-wide electronic publication, National University of Ireland, Galway. Available from: http://www.algaebase.org. Accessed Dec 10, 2011.

Huisman, J. M., De Clerck, O., Van Reine, W. F. P. \& Borowitzka, M. A. 2011. Spongophloea, a new genus of red algae based on Thamnoclonium sect. Nematophorae Webervan Bosse (Halymeniales). Eur. J. Phycol. 46:1-15.

Kang, J. W. 1966. On the geographical distribution of marine algae in Korea. Bull. Pusan Fish. Coll. 7:1-125.

Kang, J. W. 1968. Illustrated encyclopedia of fauna and flora of Korea. Vol. 8. Marine algae. Ministry of Education, Samhwa Press, Seoul, 464 pp.

Kawaguchi, S. 1993. Taxonomic notes on the Halymeniaceae
(Rhodophyta) from Japan. II. Halymenia rotunda Okamura. Jpn. J. Phycol. 41:303-313.

Kawaguchi, S., Shimada, S., Wang, H. W. \& Masuda, M. 2004. The new genus Yonagunia Kawaguchi et Masuda (Halymeniaceae, Rhodophyta), based on Y. tenuifolia Kawaguchi et Masuda sp. nov. from southern Japan and including Y. formosana (Okamura) Kawaguchi et Masuda comb. nov. from southeast Asia. J. Phycol. 40:180-192.

Kim, M. S., Kim, S. Y. \& Nelson, W. 2010. Symphyocladia lithophila sp. nov. (Rhodomelaceae, Ceramiales), a new Korean red algal species based on morphology and $r b c \mathrm{~L}$ sequences. Bot. Mar. 53:233-241.

Lee, Y. P. 2008. Marine algae of Jeju. Academy Science, Seoul, $477 \mathrm{pp}$.

Lee, Y. P. \& Kang, S. Y. 2001. A catalogue of the seaweeds in Korea. Cheju National University Press, Jeju, 662 pp.

Okamura, K. 1936. Descriptions of Japanese algae [Nippon Kaiso shi]. Uchida Rokakuho, Tokyo, 964 pp.

Stamatakis, A. 2006. RAxML-VI-HPC: maximum likelihoodbased phylogenetic analyses with thousands of taxa and mixed models. Bioinformatics 22:2688-2690.

Womersley, H. B. S. 1994. The marine benthic flora of Southern Australia, Part IIIA. Rhodophyta. Australian Biological Resources Study, Canberra, 508 pp.

Yoshida, T. 1998. Marine algae of Japan. Uchida Rokakuho Publ., Tokyo, 1222 pp. 